University of Nebraska - Lincoln

DigitalCommons@University of Nebraska - Lincoln

USDA Wildlife Services - Staff Publications

U.S. Department of Agriculture: Animal and Plant Health Inspection Service

2019

\title{
The effect of high density oral rabies vaccine baiting on rabies virus neutralizing antibody response in raccoons (Procyon lotor)
}

Kerri Pedersen

APHIS, Kerri.Pedersen@aphis.usda.gov

Amy Gilbert

USDA APHIS Wildlife Services, amy.t.gilbert@usda.aphis.gov

Eric S. Wilhelm

USDA APHIS Wildlife Services, Eric.S.Wilhelm@aphis.usda.gov

Kathleen M. Nelson

USDA APHIS, Concord, $\mathrm{NH}$

Amy J. Davis

USDA National Wildlife Research Center, Amy.J.Davis@usda.gov

See next page for additional authors

Follow this and additional works at: https://digitalcommons.unl.edu/icwdm_usdanwrc

Part of the Life Sciences Commons

Pedersen, Kerri; Gilbert, Amy; Wilhelm, Eric S.; Nelson, Kathleen M.; Davis, Amy J.; Kirby, Jordona D.; Vercauteren, Kurt C.; Johnson, Shylo; and Chipman, Richard B., "The effect of high density oral rabies vaccine baiting on rabies virus neutralizing antibody response in raccoons (Procyon lotor)" (2019). USDA Wildlife Services - Staff Publications. 2243.

https://digitalcommons.unl.edu/icwdm_usdanwrc/2243

This Article is brought to you for free and open access by the U.S. Department of Agriculture: Animal and Plant Health Inspection Service at DigitalCommons@University of Nebraska - Lincoln. It has been accepted for inclusion in USDA Wildlife Services - Staff Publications by an authorized administrator of DigitalCommons@University of Nebraska - Lincoln. 


\section{Authors}

Kerri Pedersen, Amy Gilbert, Eric S. Wilhelm, Kathleen M. Nelson, Amy J. Davis, Jordona D. Kirby, Kurt C. Vercauteren, Shylo Johnson, and Richard B. Chipman 


\title{
EFFECT OF HIGH-DENSITY ORAL RABIES VACCINE BAITING ON RABIES VIRUS NEUTRALIZING ANTIBODY RESPONSE IN RACCOONS (PROCYON LOTOR)
}

\author{
Kerri Pedersen, ${ }^{1,4}$ Amy T. Gilbert, ${ }^{1}$ Eric S. Wilhelm, ${ }^{2}$ Kathleen M. Nelson, ${ }^{3}$ Amy J. Davis, ${ }^{1}$ \\ Jordona D. Kirby, ${ }^{3}$ Kurt C. VerCauteren, ${ }^{1}$ Shylo R. Johnson, ${ }^{1}$ and Richard B. Chipman ${ }^{3}$ \\ ${ }^{1}$ US Department of Agriculture, Animal and Plant Health Inspection Service, Wildlife Services, National Wildlife Research \\ Center, 4101 LaPorte Avenue, Fort Collins, Colorado 80521, USA \\ 2 US Department of Agriculture, Animal and Plant Health Inspection Service, Wildlife Services, Abingdon, Virginia 24210, \\ USA \\ ${ }^{3}$ US Department of Agriculture, Animal and Plant Health Inspection Service, Wildlife Services, National Rabies \\ Management Program, 59 Chenell Drive, Concord, New Hampshire 03301, USA \\ ${ }^{4}$ Corresponding author (email: Kerri.Pedersen@aphis.usda.gov)
}

ABSTRACT: From 2014 to 2016, we examined the effect of distributing oral rabies vaccine baits at high density $\left(150\right.$ baits $\left./ \mathrm{km}^{2}\right)$ in an area of Virginia, US that was naïve to oral rabies vaccination prior to the study. We also compared the effect of baiting at high density in a naïve area to baiting at standard density $\left(75\right.$ baits $\left./ \mathrm{km}^{2}\right)$ in an area that had been baited annually for $12 \mathrm{yr}$. Our results suggested that rabies virus seroconversion in raccoons (Procyon lotor) gradually increased each year under the highdensity bait treatment. However, we did not detect a difference in seroconversion between bait density treatments. Virginia opossums (Didelphis virginiana) were abundant in the study area and were a potentially important nontarget species that competed for oral rabies vaccine baits, but the ratio of opossums to raccoons in this study did not affect rabies virus neutralizing antibody response of the raccoon populations.

Key words: Bait density, oral rabies vaccination, Procyon lotor, rabies, rabies virus neutralizing antibodies, raccoon.

\section{INTRODUCTION}

Raccoons (Procyon lotor) are native mammals that are ubiquitous throughout the continental US (Winkler and Jenkins 1991) and are highly adaptable to a variety of habitats and food resources (Root et al. 2009). Raccoon densities are often higher in urban and suburban areas due to the availability of anthropogenic food sources and denning sites, which inevitably results in increased interaction and conflict with humans and pets (Hoffmann and Gottschang 1977). Although raccoon conflicts are most often related to trash disturbance and denning in attics and chimneys, the transmission of zoonotic pathogens, specifically rabies virus (RABV), is of particular concern (Bigler et al. 1975) due to its high case-fatality rate (Hemachudha et al. 2002).

Mesocarnivores, including raccoons, serve as reservoirs for RABV, which is a widely distributed lyssavirus that causes fatal encephalitis in infected mammals (Rupprecht et al.
2002). A raccoon rabies epizootic emerged following translocation of rabid raccoons from Florida to the border of Virginia and West Virginia in the 1970s for a restocking program (Nettles et al. 1979; Moore 1999) and subsequently spread northward and southward along the eastern US (Guerra et al. 2003). Since 1997, efforts have been made to limit the geographic extent of the raccoon RABV variant by distributing oral rabies vaccine baits along the Appalachian Mountains in an attempt to prevent westward expansion of the virus (Ramey et al. 2008), with the ultimate goal of eliminating the variant (Slate et al. 2005).

Distribution of oral rabies vaccination (ORV) baits at the appropriate density to ensure adequate seroconversion and immunity in raccoons is paramount to a successful strategy to stop RABV circulation. Our primary objective in this study was to examine the impact of baiting at 150 baits $/ \mathrm{km}^{2}$ over 3 $\mathrm{yr}$ on rabies virus neutralizing antibody 


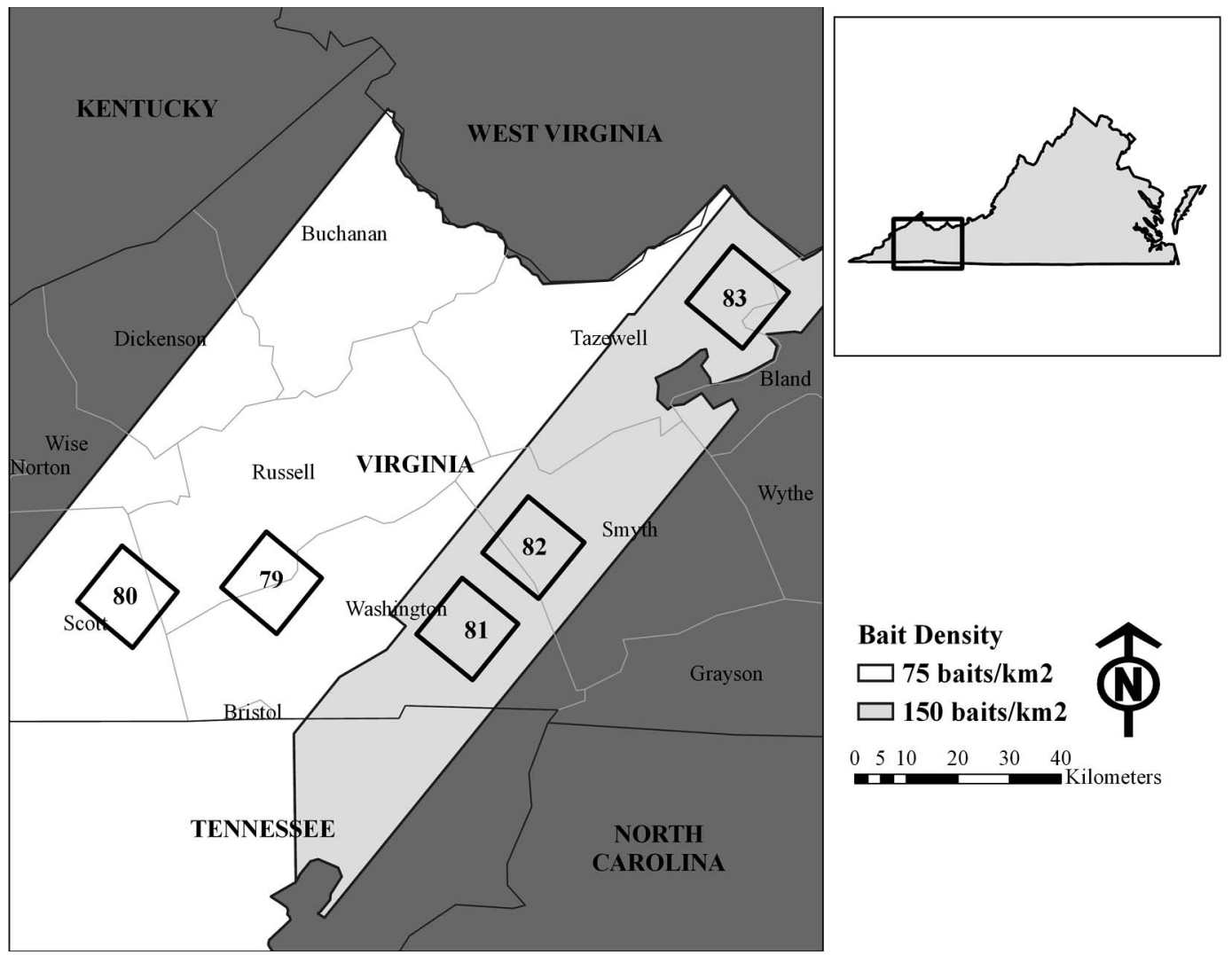

Figure 1. Study cells and oral rabies vaccination (ORV) zones in Virginia, USA where rabies vaccine baits were distributed at 75 baits $/ \mathrm{km}^{2}$ and 150 baits $/ \mathrm{km}^{2}$ from $2014-16$. Cells $79-80$ were treated with ORV at 75 baits/ $\mathrm{km}^{2}$ and cells $81-83$ were treated with ORV at 150 baits $/ \mathrm{km}^{2}$ during the study.

(RVNA) seroconversion rates. A secondary objective was to evaluate the effect of distributing ORV baits at 75 baits $/ \mathrm{km}^{2}$ in an area that had been baited for $12 \mathrm{yr}$ prior compared to 150 baits $/ \mathrm{km}^{2}$ in a naïve area. Both objectives were achieved by estimating the RVNA response in raccoons before and after ORV distribution as an index to population immunity.

\section{MATERIALS AND METHODS}

\section{Study area and design}

The study site was located in the western region of Virginia in Scott, Russell, Washington, Smyth, and Tazewell counties (Fig. 1) and included both naïve and previously baited areas. The design included five, $127-\mathrm{km}^{2}$ cells separated by at least a $4.8-\mathrm{km}$ buffer from adjacent cells, and from the edge of the larger ORV zone where all cells were located, to reduce the possibility that raccoons immigrated or emigrated from outside the study cells (Fig. 1). Two cells located within the ORV zone had been baited annually at 75 baits $/ \mathrm{km}^{2}$ (standard bait density), with $750 \mathrm{~m}$ flight-line spacing since 2002, and were sampled to take advantage of an ongoing management activity (cells 79-80; Fig. 1). Three additional cells were established in an ORV-naïve area and baited annually at 150 baits $/ \mathrm{km}^{2}$ with $375 \mathrm{~m}$ between parallel flight lines during aerial distribution of baits (cells 81-83; Fig. 1). The flight-line spacing was adjusted between treatments to achieve the desired bait densities.

\section{Oral rabies vaccine bait and bait distribution}

Baits consisted of a plastic sachet containing 1.8 $\mathrm{mL}$ of vaccinia-rabies glycoprotein $(\mathrm{V}-\mathrm{RG})$ recombinant vaccine (RABORAL V-RG ${ }^{\circledR}$, Merial, Inc., Duluth, Georgia, USA) coated with wax and fishmeal crumbles (coated sachets) or encased in a solid square fishmeal block (Maki et al. 2017). 
There was no biomarker present in the baits. Coated sachets were distributed in October each year from 2014 to 2016 by fixed-wing aircraft in the majority of the ORV zone and by helicopter in urban and suburban areas. Fishmeal blocks (polymers) were distributed by vehicle in core urban areas.

\section{Animal handling and sampling}

Random points were generated each year using Geospatial Modeling Environment (Beyer 2012) to guide trap placement in study cells. Each cell was divided into four quadrants with seven to nine random points generated for each quadrant. Traps were placed within $800 \mathrm{~m}$ of six of the random points in three of the quadrants and seven random points in the fourth quadrant, with six traps at each point for a total of 150 traps/cell with at least $30.5 \mathrm{~m}$ between each trap. Traps were checked daily and moved every $2-3 \mathrm{~d}$ if no unique raccoons had been captured. Each cell was trapped for 10 consecutive nights in July or August, $6-8$ wk prior to baiting, and again for 10 consecutive nights in November approximately 4 wk after baiting in 2014, 2015, and 2016). Live traps (Tomahawk Live Trap, Hazelhurst, Wisconsin, USA) were baited with marshmallows and Hard-Core Raccoon Lure (Minnesota Trapline Products, Pennock, Minnesota, USA). Upon capture, we anesthetized raccoons, striped skunks (Mephitis mephitis), red foxes (Vulpes vulpes), and gray foxes (Urocyon cinereoargenteus) with a $5: 1$ ratio of ketamine $(10 \mathrm{mg} / \mathrm{kg})$ to xylazine $(2 \mathrm{mg} /$ $\mathrm{kg}$ ) via intramuscular injection based on estimated body weight (Kreeger and Arnemo 2012). All other species were released at the point of capture without sampling.

While anesthetized, each target animal received a unique metal ear tag (National Band and Tag Company, Newport, Kentucky, USA) and sex, relative age (juvenile or adult), weight, and general condition were recorded. Approximately $5 \mathrm{~mL}$ of blood were collected from a peripheral vein of each animal, and the first premolar tooth was collected from a subset of target species. Animals that were recaptured within a given prebait or postbait trapping effort were not resampled.

Animals were released at the point of capture after sampling and upon recovery from anesthesia. The only exception was for suspected rabid or seriously injured animals. These animals were humanely euthanized with either a properly placed gunshot or by placing the entire trap with the anesthetized animal in a carbon dioxide gas chamber in accordance with the American Veterinary Medical Association's Guidelines on Euthanasia (Leary et al. 2013).

\section{Rabies diagnostics}

Animal sera were submitted to the Centers for Disease Control and Prevention in Atlanta, Georgia for testing. Serum RVNA titers were determined using the rapid fluorescent focus inhibition test (RFFIT; Smith et al. 1996). A titer value $>0.05$ international units $/ \mathrm{mL}$ (IU/mL) was considered positive (Blanton et al. 2018). The effect of setting the RFFIT cut-off value at 0.1 and $\geq 0.5 \mathrm{IU} / \mathrm{mL}$ (Moore and Hanlon 2010) was also examined (see Supplementary Material Table S1). Sera from four raccoons could not be evaluated at the cut-off value due to poor sample quality and were excluded from further analyses. A cross-section of the brain stem tissue from euthanized animals was tested for RABV by trained Wildlife Services personnel using a direct rapid immunohistochemistry test (Lembo et al. 2006).

\section{Age determination}

Teeth were shipped to Matson's Laboratory LLC (Manhattan, Montana) for age determination. The lines in the cementum or dentin annuli of a cross-section of teeth were examined using a compound microscope and ultraviolet-light filters (Johnston et al. 1999). When available, age determined by this method was used instead of the relative age assessment in the field. Animals less than $1 \mathrm{yr}$ old were classified as juveniles and those 1 yr old or older as adults.

\section{Data analysis}

Our primary objective was to examine the cumulative effect and variability of high-density baiting at 150 baits $/ \mathrm{km}^{2}$ over $3 \mathrm{yr}$. We measured RVNA seroprevalence in raccoons before and after ORV baiting. Our analysis focused on raccoons because they are the primary reservoir of raccoon variant RABV and represented 98\% $(2,859 / 2,917)$ of the samples collected. The impact of baiting at high density over $3 \mathrm{yr}$ on RVNA seroconversion was examined with a linear mixed model in Program R, package lme4 (Bates et al. 2015; R Core Team 2016). The fixed effects included the year and the ratio of Virginia opossums (Didelphis virginiana) to raccoons captured as covariates and a random effect of study cell. The ratio of opossums to raccoons was examined in the analysis due to concerns that they were a nontarget species competing with raccoons for baits.

In addition, to achieve our secondary objective of comparing the treatments, we used generalized linear mixed models to examine the probabilities that individual raccoons would be RVNA-positive before and after ORV in each bait density 
TABle 1. Habitat composition (\%) of study cells in Virginia, USA where oral rabies vaccination baits were distributed at 75 baits $/ \mathrm{km}^{2}$ (study cells 79-80) or 150 baits $/ \mathrm{km}^{2}$ (study cells 81-83) from 2014-16.

\begin{tabular}{lrrrrr}
\hline & \multicolumn{5}{c}{ Study cell } \\
\cline { 2 - 6 } \multicolumn{1}{c}{ Habitat type } & 79 & 80 & 81 & 82 & 83 \\
\hline Developed & 4.0 & 5.2 & 6.5 & 7.9 & 5.7 \\
Forested & 64.8 & 45.5 & 31.0 & 47.0 & 61.8 \\
Planted-cultivated & 29.0 & 44.7 & 61.5 & 43.8 & 17.9 \\
Other & 2.2 & 4.6 & 1.0 & 1.3 & 14.6 \\
\hline
\end{tabular}

treatment area. Bait density ( 75 or 150 baits $/ \mathrm{km}^{2}$ ) was a fixed effect and the random effect was study cell. We examined the cumulative effect of RVNA response by year.

We performed model selection using the second order Akaike's information criteria (AICc) and considered models within two AICc values of the top model as competitive (Burnham and Anderson 2002). When model uncertainty occurred, we used model averaging to estimate the response variable (Burnham and Anderson 2002).

\section{RESULTS}

\section{Bait distribution}

Based on the 2011 National Land Cover Database (Homer et al. 2015), each study cell contained a combination of developed, forested, planted or cultivated, and other habitats with some variation among them (Table 1). During the study, a total of 779,622 and 645,580 baits were distributed across the 75 and 150 baits $/ \mathrm{km}^{2}$ ORV zones, respectively, which were baited during the same time frames, and encompassed areas in Virginia and neighboring states (Fig. 1 and Table 2). The standard-density ORV zone consisted of $5,121 \mathrm{~km}^{2}$ and the high-density ORV zone encompassed 2,061 km². Actual bait densities for the standard bait density ORV zone were 75,75 , and 74 baits $/ \mathrm{km}^{2}$ in 2014, 2015, and 2016, respectively. For the high-density ORV zone, the actual bait densities were 149, 153, and 148 baits $/ \mathrm{km}^{2}$ in 2014, 2015, and 2016, respectively. The actual bait densities accounted for areas where baiting was not permitted such as developed areas, swimming pools, interstate highways, large bodies of water, and wilderness areas.

\section{Trapping}

During the 3-yr study, 2,640 unique and 219 recaptured raccoons were sampled. Recaptured animals were always trapped in the same study cell as the initial capture. In addition, six gray foxes, one red fox, and 57 striped skunks were sampled. Opossums were the only abundant nontarget species, with 1,935 captured across all study cells and years (Table 3). However, some of the opossums may have been recaptures, as they were released without sampling or marking, thus potentially inflating the ratios.

\section{Rabies diagnostics}

Thirty raccoons were euthanized during the course of the study due to abnormal behavior or injury and all tested RABV-negative. The

TABLE 2. Distribution dates and number of oral rabies vaccination baits by type of distribution and density in Virginia, USA from 2014-16.

\begin{tabular}{|c|c|c|c|c|c|c|c|}
\hline \multirow[b]{2}{*}{ Year } & \multirow[b]{2}{*}{ Bait distribution } & \multicolumn{2}{|c|}{75 baits $/ \mathrm{km}^{2}$} & \multicolumn{2}{|c|}{150 baits $/ \mathrm{km}^{2}$} & \multirow{2}{*}{$\begin{array}{l}\text { Prebait } \\
\text { trapping }\end{array}$} & \multirow{2}{*}{$\begin{array}{l}\text { Postbait } \\
\text { trapping }\end{array}$} \\
\hline & & Aerial $^{1}$ & Ground & Aerial & Ground & & \\
\hline 2014 & 27 September-6 October & 276,167 & 2,865 & 208,103 & 7,838 & $\begin{array}{l}\text { 15-25 July, } \\
5-15 \text { August }\end{array}$ & 4-14 November \\
\hline 2015 & 28 September-5 October & 256,640 & 2,877 & 240,201 & 7,837 & 21-31 July & 4-14 November \\
\hline 2016 & 21 September-10 October & 240,831 & 242 & 175,523 & 6,078 & 19-29 July & 8-18 November \\
\hline Totals & & 779,367 & 8,684 & 624,921 & 21,753 & $\mathrm{NA}^{\mathrm{b}}$ & $N A^{b}$ \\
\hline
\end{tabular}

a Includes distribution by both fixed-wing and rotary wing aircraft.

${ }^{\mathrm{b}} \mathrm{NA}=$ not applicable. 
TABLE 3. Comparison of the number of raccoons (Procyon lotor) and Virginia opossums (Didelphis virginiana) trapped in Virginia, USA by study cell (79-83) at different oral rabies vaccination bait densities $\left(75 \mathrm{baits}^{\mathrm{k}} \mathrm{km}^{2} \mathrm{or}\right.$ 150 baits $/ \mathrm{km}^{2}$ ) from $2014-16$ during prebait and postbait trapping.

\begin{tabular}{|c|c|c|c|c|c|c|c|c|c|c|}
\hline \multirow[b]{3}{*}{ Year } & \multicolumn{4}{|c|}{ No. recovered at 75 baits $/ \mathrm{km}^{2}$} & \multicolumn{6}{|c|}{ No. recovered at 150 baits $/ \mathrm{km}^{2}$} \\
\hline & \multicolumn{2}{|c|}{ Cell 79} & \multicolumn{2}{|c|}{ Cell 80} & \multicolumn{2}{|c|}{ Cell 81} & \multicolumn{2}{|c|}{ Cell 82} & \multicolumn{2}{|c|}{ Cell 83} \\
\hline & Prebait & Postbait & Prebait & Postbait & Prebait & Postbait & Prebait & Postbait & Prebait & Postbait \\
\hline \multicolumn{11}{|l|}{2014} \\
\hline Raccoon & 92 & 35 & 92 & 70 & 143 & 62 & 98 & 71 & 105 & 55 \\
\hline Opossum & 22 & 64 & 14 & 54 & 83 & 59 & 34 & 63 & 7 & 7 \\
\hline \multicolumn{11}{|l|}{2015} \\
\hline Raccoon & 123 & 53 & 102 & 58 & 133 & 91 & 79 & 71 & 146 & 110 \\
\hline Opossum & 54 & 76 & 94 & 201 & 64 & 129 & 43 & 76 & 7 & 28 \\
\hline \multicolumn{11}{|l|}{2016} \\
\hline Raccoon & 137 & 44 & 123 & 22 & 183 & 91 & 133 & 77 & 169 & 87 \\
\hline Opossum & 90 & 63 & 174 & 70 & 88 & 69 & 72 & 89 & 16 & 25 \\
\hline \multicolumn{11}{|l|}{ Total } \\
\hline Raccoon & 352 & 132 & 317 & 150 & 459 & 162 & 310 & 219 & 420 & 252 \\
\hline Opossum & 166 & 203 & 282 & 325 & 235 & 257 & 149 & 228 & 30 & 60 \\
\hline
\end{tabular}

difference in raccoon RVNA seroprevalence (postbait minus prebait) in the study cells baited at high density marginally increased during the study (Fig. 2, Table 4, and Supplementary Table S2; the intercept-only

TABLE 4. Model results for the differences in prebait and postbait seropositive rates at the study cell level from raccoons (Procyon lotor) in areas baited at 75 baits $/ \mathrm{km}^{2}$ or 150 baits $/ \mathrm{km}^{2}$ in Virginia, USA from 2014-16. The Akaike's information criteria (AICc) for the top model is 6.67 for the 75 baits $/ \mathrm{km}^{2}$ area and -14.28 for the 150 baits $/ \mathrm{km}^{2}$ area.

\begin{tabular}{|c|c|c|c|c|}
\hline Covariates & $\mathrm{K}^{\mathrm{a}}$ & $\triangle \mathrm{AICc}$ & $\omega^{\mathrm{b}}$ & $\mathrm{LL}^{\mathrm{c}}$ \\
\hline \multicolumn{5}{|l|}{75 baits $/ \mathrm{km}^{2}$} \\
\hline Intercept only & 3 & 0 & 1 & 5.67 \\
\hline $\begin{array}{l}\text { Opossum to } \\
\text { raccoon ratio }\end{array}$ & 4 & 19.16 & 0 & 11.08 \\
\hline Year & 4 & 26.42 & 0 & 7.46 \\
\hline \multicolumn{5}{|l|}{150 baits $/ \mathrm{km}^{2}$} \\
\hline Intercept only & 3 & 0 & 0.71 & 12.54 \\
\hline Year & 4 & 2.03 & 0.26 & 15.13 \\
\hline $\begin{array}{l}\text { Opossum to } \\
\text { raccoon ratio }\end{array}$ & 4 & 5.41 & 0.05 & 13.43 \\
\hline $\begin{array}{l}\text { Year }+ \text { opossum to } \\
\text { raccoon ratio }\end{array}$ & 5 & 9.46 & 0.01 & 17.41 \\
\hline
\end{tabular}

${ }^{\mathrm{a}} \mathrm{K}=$ no. of parameters.

${ }^{\mathrm{b}} \omega=$ AICc model weight.

${ }^{\mathrm{c}} \mathrm{LL}=\mathrm{Log}$ likelihood of the model. model had $71 \%$ of the model weight). In the standard bait density study cells, ORV appeared to be maintaining the RVNA seroprevalence in the raccoon population (Fig. 2 and Table 4; the intercept-only model had $100 \%$ of the model weight). The ratio of opossums to raccoons had no effect on raccoon population RVNA response at high or standard bait density treatments (Table 4).

The probability of an individual raccoon testing RVNA-positive post-ORV increased with year and was marginally higher (but confidence intervals [CIs] overlapped) for study cells baited at 150 baits $/ \mathrm{km}^{2}$ compared to 75 baits $/ \mathrm{km}^{2}$ (Fig. 3, Table 5, and Supplementary Table S2). Post-ORV baiting seroprevalence tended to increase by year for both bait-density treatments. Year was less influential for pre-ORV baiting, but the trends were different by bait-density treatments: there was a neutral or slightly negative trend for standard-density baiting compared to a slightly positive trend for high-density baiting (Fig. 3 and Table 5). Although the model averaged estimates showed a trend in bait density, the confidence intervals overlapped, indicating no apparent difference between standard- and high-density baiting (Fig. 3). We reran the linear bait density effect model 


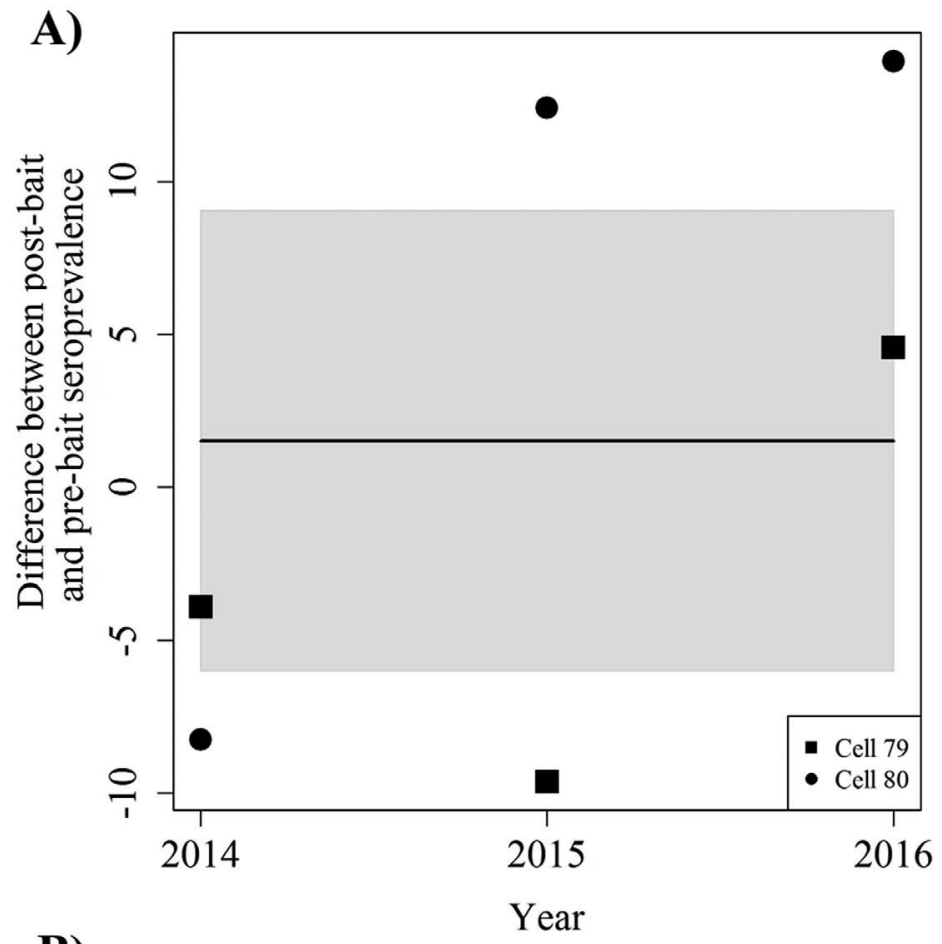

B)

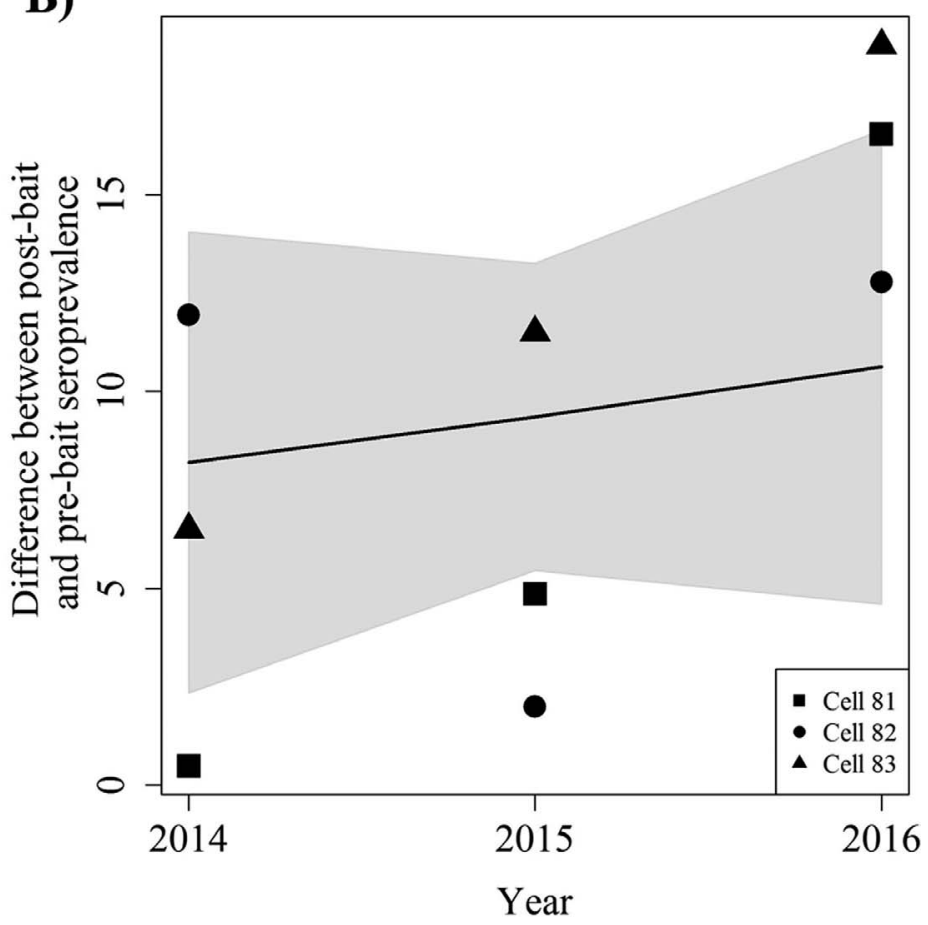

Figure 2. Effect of year on the difference observed between postbait and prebait rabies virus neutralizing antibody (RVNA) seroprevalence in raccoons (Procyon lotor) captured in study cells in Virginia, USA for two conditions: (A) Seroprevalence in raccoons where oral rabies vaccination (ORV) baits were distributed at 75 baits $/ \mathrm{km}^{2}$ in areas where ORV had been conducted annually for $12 \mathrm{yr}$ prior to the study. (B) Seroprevalence in raccoons where oral rabies vaccination baits were distributed at 150 baits $/ \mathrm{km}^{2}$ in an ORV-naïe area. The lines represent the change in RVNA with 95\% confidence interval (shaded regions). 

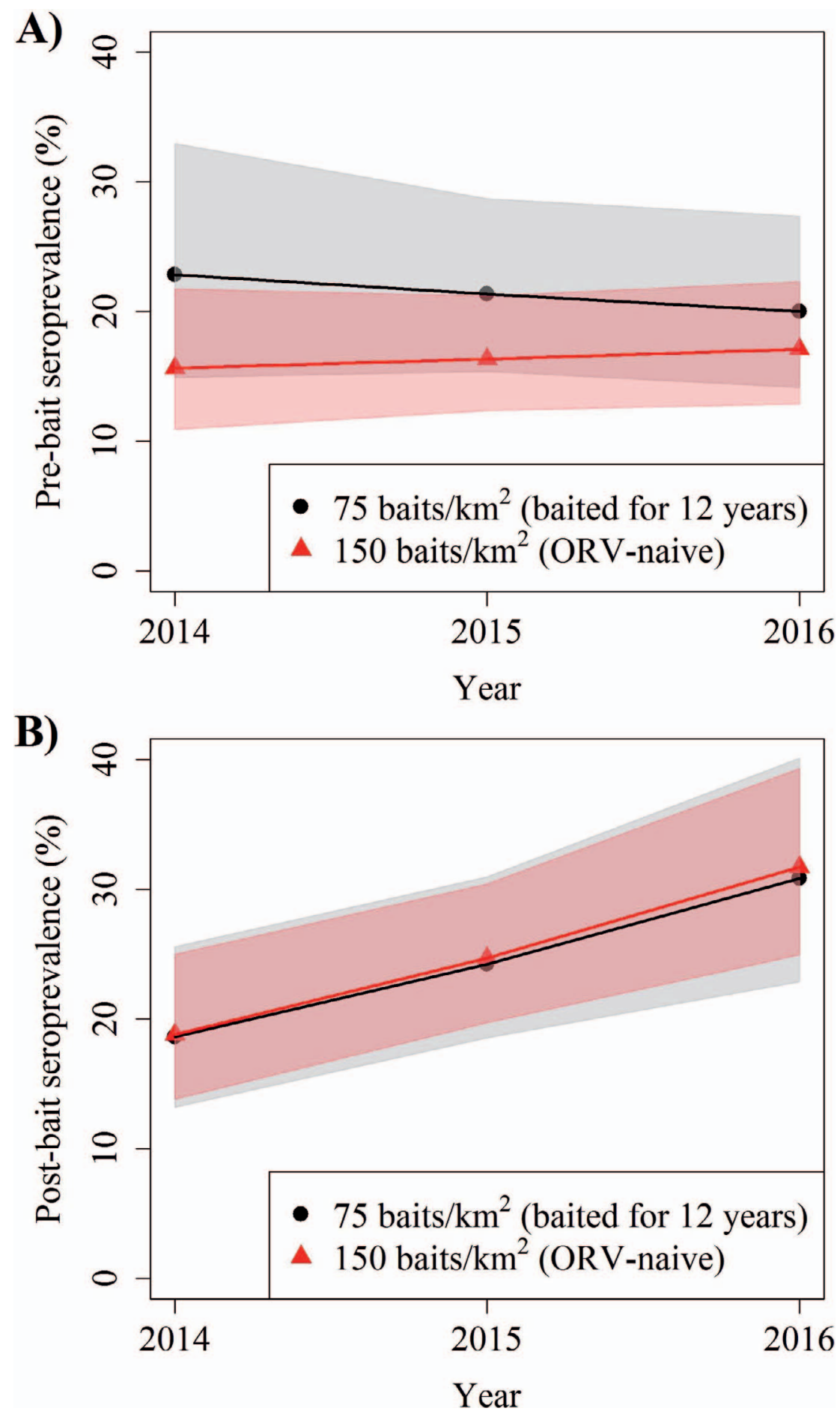

Figure 3. Effect of year and bait density (A) before (prebait) and (B) after (postbait) oral rabies vaccination (ORV) distribution in Virginia, USA from 2014-16 based on the generalized linear mixed model averaged probability of an individual raccoon (Procyon lotor) being rabies virus neutralizing antibody (RVNA) seropositive. The shaded areas represent the $95 \%$ confidence intervals for each of the RVNA seroprevalences based on bait density. 
TABle 5. Model results for logistic regression on raccoons (Procyon lotor) captured in Virginia, USA from 2014-16, prior to oral rabies vaccination (prebait) and after baiting (postbait), and tested for rabies virus neutralizing antibodies at the individual raccoon level. The second order Akaike information criterion (AICc) for the top model for prebait was 1,766.65, and for postbait the AICc for the top model was 1,119.76.

\begin{tabular}{lcccc}
\hline \multicolumn{1}{c}{ Covariates } & $\mathrm{K}^{\mathrm{a}}$ & $\Delta \mathrm{AICc}$ & $\omega^{\mathrm{b}}$ & $\mathrm{LL}^{\mathrm{c}}$ \\
\hline Prebait & & & & \\
$\quad$ Year $\times$ bait density & 5 & 0 & 0.41 & -878.31 \\
$\quad$ Bait density & 3 & 0.99 & 0.25 & -880.81 \\
$\quad$ Intercept only & 2 & 1.61 & 0.18 & -882.13 \\
$\quad$ Year + bait density & 4 & 3.00 & 0.09 & -880.81 \\
$\quad$ Year & 3 & 3.62 & 0.07 & -882.13 \\
Postbait & & & & \\
$\quad$ Year & 3 & 0 & 0.65 & -556.87 \\
$\quad$ Year + bait density & 4 & 1.95 & 0.24 & -556.83 \\
$\quad$ Year $\times$ bait density & 5 & 3.60 & 0.11 & -556.67 \\
$\quad$ Intercept only & 2 & 11.11 & 0.00 & -563.50 \\
$\quad$ Treatment & 3 & 12.81 & 0.00 & -563.34 \\
\hline $\begin{array}{l}{ }^{\mathrm{a}} \mathrm{K}=\text { no. of parameters. } \\
{ }_{\mathrm{b}} \omega=\text { AICc model weight. }\end{array}$ & & & \\
${ }^{\mathrm{c}}$ LL $=$ Log likelihood of the model. & &
\end{tabular}

with the actual bait densities and confirmed that the results and interpretation did not change.

\section{DISCUSSION}

Although we observed a marginal increase in raccoon RVNA seroprevalence in the highdensity bait area during the study (Fig. 2 and Table 4), in 2016, after $3 \mathrm{yr}$ of baiting, the postbait seroprevalence was only $33.3 \%$ (95\% CI: 27.8-39.3) In 2014, the postbait prevalence was $19.2 \%$ (95\% CI: $14.2-25.4)$ and in 2015 it was $25.0 \%$ (95\% CI: $20.2-30.5$ ). These seroprevalences were considerably less than the estimated $60 \%$ population immunity reported as necessary to control and prevent RABV circulation in raccoons (Rees et al. 2013). A gradual increase in RVNA seroprevalence in raccoons resulting from consecutive ORV campaigns has also been previously reported (Robbins et al. 1998; Sattler et al. 2009). In our study, even though our results suggested an increase in RVNA seroprevalence rates each year, the difference between postbait and prebait serology at high density only increased marginally (Fig. 2). If the effect of baiting had reached saturation level or a plateau, the difference between prebait and postbait RVNA seroprevalence would have started decreasing, assuming the prebait seroprevalence had increased. Because we did not observe a declining trend of ORV impact, further increases in RVNA seroprevalence could be expected if high-density baiting had continued, and the saturation level may have been higher than that of the standard-density areas. This impact was weakly supported when comparing the prebait RVNA seroprevalence between the two density treatments over the $3 \mathrm{yr}$ (Fig. 3). While the prebait seroprevalence was maintained or even slightly higher in the high-density study areas, it had a slightly negative (but not significant) relationship in the standard-density areas. After $12 \mathrm{yr}$ of baiting at standard density, no further gains in raccoon population seroprevalence were being realized.

Though not all of our study cells were in ORV-naïve areas, we observed approximately the same postbait effect on seroconversion over time whether baiting at high or standard density. This is similar to findings reported in a study conducted in Ohio where no advantage was observed for raccoon population RVNA seroprevalence when baiting at 150 baits $/ \mathrm{km}^{2}$ compared to 75 baits $/ \mathrm{km}^{2}$, although the actual number of baits distributed may have affected the outcome (Sattler et al. 2009). In a 1-yr study conducted in Pennsylvania, increased RVNA response was detected in raccoons captured in areas baited at 150 baits $/ \mathrm{km}^{2}$ compared to $75 \mathrm{baits} / \mathrm{km}^{2}$, but the difference was insufficient to warrant the added cost associated with baits and bait distribution (Pedersen et al. 2018). Because baiting for $3 \mathrm{yr}$ at $150 \mathrm{baits} / \mathrm{km}^{2}$ produced a similar result to baiting at 75 baits $/ \mathrm{km}^{2}$ for 12 yr (Fig. 3), baiting at high density for a shorter period of time may be more cost effective. Bait density is one of the primary factors affecting the cost of ORV campaigns, and is thought to have a direct impact on effectiveness, although studies specifically evaluating 
the impacts of bait density on case reduction outcomes in raccoons have been lacking.

Elmore et al. (2017) summarized various ORV bait density studies that have been conducted to evaluate the RABV antibody seroprevalence response in North American target wild carnivore species. Due to the wide variability in locations, bait densities, diagnostic tests, and even the cut-off value used to identify seropositive samples, meaningful comparisons across studies are difficult (Moore et al. 2017). As summarized by Elmore et al. (2017), the postbait seroprevalence in raccoons determined in other studies in the US was highly variable and ranged from $8-77 \%$, although the seroprevalence is typically $30 \%$ after ORV baiting campaigns (Slate et al. 2009).

Baiting success can be affected by a number of factors, not only related directly to the bait itself (e.g., palatability) but also to the availability of other foods which can be affected by habitat type, as well as to nontarget species competing for baits. Although habitat varied slightly among our study cells, it was not a significant confounder. Despite the apparent difference of cell 83, where fewer opossums were captured compared to other study cells (Table 3), the population-level RVNA seroconversion of raccoons was similar in each of the study cells, indicating that opossums likely did not impact baiting success. In areas with high opossum densities and standard bait density (75 baits $/ \mathrm{km}^{2}$ ) applications, opossums may have a greater impact on the number of baits available to raccoons even though this was not supported in our study. Another possibility for not observing an opossum-related effect may be because we accounted for cell variability in the analysis by using a random effect. Because there were only two or three cells per baitdensity treatment, the effect of opossums may have been diluted by accounting for variability among cells. Opossums were by far the most abundant of all nontarget species captured $(1,935$ of 2,363$)$. Other studies have reported opossums as a common nontarget species for ORV (Sattler et al. 2009; Pedersen et al. 2018) and are a concern because they may consume baits meant for target species (Olson et al. 2000; Smyser et al. 2010).

Additional studies to quantify bait uptake in opossums are recommended, as they are the most likely nontarget species to compete for baits in similar rural habitats. Distribution of higher densities of baits in areas where opossum densities are known to be elevated may be warranted to ensure sufficient baits are available for target species. As has been suggested in other studies, baiting at densities higher than 75 baits $/ \mathrm{km}^{2}$ with RABORAL V$\mathrm{RG}$ is probably not worth the added expense except in contingency areas, new epizootic areas, or perhaps in urban or suburban areas where raccoon densities are significantly higher than in rural areas. However, additional studies to examine high-density baiting $(\geq 5$ yr) may yield valuable insights into long-term effects on raccoon population immunity.

\section{ACKNOWLEDGMENTS}

We thank all of the Wildlife Services personnel that trapped animals for this study as well as Bob Hale, Bradley Hicks, and Betsy Haley for executing bait distribution operations. Mention of trade names or commercial products in this work is solely for the purpose of providing specific information and does not imply recommendation or endorsement by the US Department of Agriculture.

\section{SUPPLEMENTARY MATERIAL}

Supplementary material for this article is online at http://dx.doi.org/10.7589/2018-05-138.

\section{LITERATURE CITED}

Bates D, Mächler M, Bolker BM, Walker SC. 2015. Fitting linear mixed-effects models using lme4. J Stat Softw 67:1-48.

Beyer H. 2012. Geospatial modelling environment. http:// www.spatialecology.com/gme/index.htm. Accessed February 2018.

Bigler WJ, Jenkins JH, Cumbie PM, Hoff GL, Prather EC. 1975. Wildlife and environmental health: Raccoons as indicators of zoonoses and pollutants in southeastern United States. J Am Vet Med Assoc 167: 592-597.

Blanton JD, Niezgoda M, Hanlon CA, Swope CB, Suckow J, Saidy B, Nelson KM, Chipman RB, Slate D. 2018. Evaluation of oral rabies vaccination: Protection 
against rabies in wild caught raccoons (Procyon lotor). J Wildl Dis 54:520-527.

Burnham KP, Anderson DR. 2002. Model selection and multimodel inference: A practical information-theoretic approach. 2nd Ed. Springer-Verlag, New York, New York, 487 pp.

Elmore SA, Chipman RB, Slate D, Huyvaert KP, VerCauteren KC, Gilbert AT. 2017. Management and modeling approaches for controlling raccoon rabies: The road to elimination. PLoS Negl Trop Dis 11:e005249.

Guerra MA, Curns AT, Rupprecht CE, Hanlon CA, Krebs JW, Childs JE. 2003. Skunk and raccoon rabies in the eastern United States: Temporal and spatial analysis. Emerg Infect Dis 9:1143-1150.

Hemachudha T, Laothamatas J, Rupprecht CE. 2002. Human rabies: A disease of complex neuropathogenetic mechanisms and diagnostic challenges. Lancet Neurol 1:101-109.

Hoffmann CO, Gottschang JL. 1977. Numbers, distribution, and movements of a raccoon population in a suburban residential community. J Mammal 58:623636.

Homer C, Dewitz J, Yang L, Jin S, Danielson P, Xian G, Coulston J, Herold N, Wickham J, Megown K. 2015. Completion of the 2011 National Land Cover Database for the conterminous United StatesRepresenting a decade of land cover change information. Photogramm Eng Rem Sens 81:345-354.

Johnston DH, Joachim DG, Bachmann P, Kardong KV, Stewart RE, Dix LM, Strickland MA, Watt ID. 1999. Aging furbearers using tooth structure and biomarkers. In: Wild furbearer management and conservation in North America, Novak M, Baker JA, Obbard ME, Malloch B, editors. Ontario Fur Managers Federation, Sault Ste Marie, Ontario, Canada, pp. 228-243.

Kreeger TJ, Arnemo JM. 2012. Handbook of wildlife chemical immobilization. 4th Ed. International Wildlife Veterinary Services, Laramie, Wyoming, 448 pp.

Leary S, Underwood W, Anthony R, Cartner S, Corey D, Grandin T, Greenacre C, Gwaltney-Brant S, McCrackin MA, Meyer R, et al. 2013. American Veterinary Medical Association guidelines for the euthanasia of animals: 2013 edition. American Veterinary Medical Association, Schaumburg, Illinois, $102 \mathrm{pp}$.

Lembo T, Niezgoda M, Velasco-Villa A, Cleaveland S, Ernest E, Rupprecht CE. 2006. Evaluation of a direct, rapid immunohistochemical test for rabies diagnosis. Emerg Infect Dis 12:310-313.

Maki J, Guiot A-L, Aubert M, Brochier B, Cliquet F, Hanlon CA, King R, Oertli EH, Rupprecht CE, Schumacher C, et al. 2017. Oral vaccination of wildlife using a vaccinia-rabies-glycoprotein recombinant virus vaccine (RABORAL V-RG ${ }^{\circledR}$ ): A global review. Vet Res 48:57.

Moore DA. 1999. Spatial diffusion of raccoon rabies in Pennsylvania, USA. Prev Vet Med 40:19-32.

Moore SM, Gilbert A, Vos A, Freuling CM, Ellis C, Kliemt J, Müller T. 2017. Rabies virus antibodies from oral vaccination as a correlate of protection against lethal infection in wildlife. Trop Med Infect Dis 2:31.

Moore SM, Hanlon CA. 2010. Rabies-specific antibodies: Measuring surrogates of protection against a fatal disease. PLoS Negl Trop Dis 4:e595.

Nettles VF, Shaddock JH, Sikes RK, Reyes CR. 1979. Rabies in translocated raccoons. Am J Public Health 69:601-602.

Olson CA, Mitchell KD, Werner PA. 2000. Bait ingestion by free-ranging raccoons and nontarget species in an oral rabies vaccine field trial in Florida. J Wildl Dis 36:734-743.

Pedersen K, Schmit BS, DeLiberto TJ, Suckow JR, Davis AJ, Slate D, Chipman RB, Hale RL, Gilbert AT. 2018. Raccoon (Procyon lotor) biomarker and rabies antibody response to varying oral rabies vaccine bait densities in northwestern Pennsylvania. Heliyon 4: e00754.

R Core Team. 2016. R: A language and environment for statistical computing. R Foundation for Statistical Computing, Vienna, Austria. https://www.R-project. org/. Accessed January 2018.

Ramey PC, Blackwell BF, Gates RJ, Slemons RD. 2008. Oral rabies vaccination of a northern Ohio raccoon population: Relevance of population density and prebait serology. J Wildl Dis 44:553-568.

Rees EE, Pond BA, Tinline RR, Bélanger D. 2013. Modelling the effect of landscape heterogeneity on the efficacy of vaccination for wildlife infectious disease control. J Appl Ecol 50:881-891.

Robbins AH, Borden MD, Windmiller BS, Niezgoda M, Marcus LC, O'Brien SM, Kreindel SM, McGuill MW, Demaria A Jr, Rupprecht CE, et al. 1998. Prevention of the spread of rabies to wildlife by oral vaccination of raccoons in Massachusetts. J Am Vet Med Assoc 213:1407-1412.

Root JJ, Puskas RB, Fischer JW, Swope CB, Neubaum MA, Reeder SA, Piaggio AJ. 2009. Landscape genetics of raccoons (Procyon lotor) associated with ridges and valleys of Pennsylvania: Implications for oral rabies vaccination programs. Vector Borne Zoonotic Dis 9:583-588.

Rupprecht CE, Hanlon CA, Hemachudha T. 2002. Rabies re-examined. Lancet Infect Dis 2:327-343.

Sattler AC, Krogwold RA, Wittum TE, Rupprecht CE, Algeo TP, Slate D, Smith KA, Hale RL, Nohrenberg GA, Lovell CD, et al. 2009. Influence of oral rabies vaccine bait density on rabies seroprevalence in wild raccoons. Vaccine 27:7187-7193.

Slate D, Algeo TP, Nelson KM, Chipman RB, Donovan D, Blanton JD, Niezgoda M, Rupprecht CE. 2009. Oral rabies vaccination in North America: Opportunities, complexities, and challenges. PLoS Negl Trop Dis 3:e549.

Slate D, Rupprecht CE, Rooney JA, Donovan D, Lein DH, Chipman RB. 2005. Status of oral rabies vaccination in wild carnivores in the United States. Virus Res 111:68-76. 
Smith JS, Yager PA, Baer GM. 1996. A rapid fluorescent focus inhibition test (RFFIT) for determining rabies virus-neutralizing antibody. In: Laboratory techniques in rabies, Meslin F-X, Kaplan MM, Koprowski $\mathrm{H}$, editors. World Health Organization, Geneva, Switzerland, pp. 181-192.

Smyser TJ, Beasley JC, Olson ZH, Rhodes OE Jr. 2010. Use of rhodamine $\mathrm{B}$ to reveal patterns of interspecific competition and bait acceptance in raccoons. J Wildl Manage 74:1405-1416.

Winkler WG, Jenkins SR. 1991. Raccoon rabies. In: The natural history of rabies, 2nd Ed., Baer GM, editor. CRC Press, Inc., Boca Raton, Florida, pp. 325-340.

Submitted for publication 21 May 2018.

Accepted 11 September 2018. 
Supplementary materials for Journal of Wildlife Diseases DOI: 10.7589/2018-05-138: Kerri Pedersen, Amy T. Gilbert, Eric S. Wilhelm, Kathleen M. Nelson, Amy J. Davis, Jordona D. Kirby, Kurt C. VerCauteren, Shylo R. Johnson, Richard B. Chipman. EVALUATION OF HIGH DENSITY ORAL RABIES VACCINE BAITING ON RABIES VIRUS NEUTRALIZING ANTIBODY RESPONSE IN RACCOONS (PROCYON LOTOR)

Supplemental Table 1. Relative number of target species captured before and after oral rabies vaccine bait distribution in Virginia from 2014-2016. Animals were tested for rabies virus neutralizing antibodies with the rapid fluorescent focus inhibition test and are grouped by titer (measured in international units $/ \mathrm{mL}$ ).

\begin{tabular}{lllll}
\hline Species (n) & $<0.05$ & $.05-0.10$ & $.11-0.49$ & $\geq 0.5$ \\
\hline Gray Fox $^{\mathrm{a}}$, Urocyon cinereoargenteus (6) & 4 & 0 & 0 & 0 \\
Raccoon, Procyon lotor (2859) & 2257 & 206 & 312 & 79 \\
Red Fox, Vulpes vulpes (1) & 0 & 0 & 0 & 1 \\
Striped Skunk ${ }^{1}$, Mephitis mephitis (57) & 49 & 4 & 1 & 0 \\
\hline
\end{tabular}

${ }^{a}$ No blood was available for testing two foxes and three striped skunks 
Supplemental Table 2. Antibody prevalence of raccoons (Procyon lotor) captured at five study sites in Virginia prior to and after oral rabies vaccine bait distribution of 75 baits $/ \mathrm{km}^{2}$ or 150 baits $/ \mathrm{km}^{2}$ from 2014-2016 and tested for antibodies using the rapid fluorescent focus inhibition test.

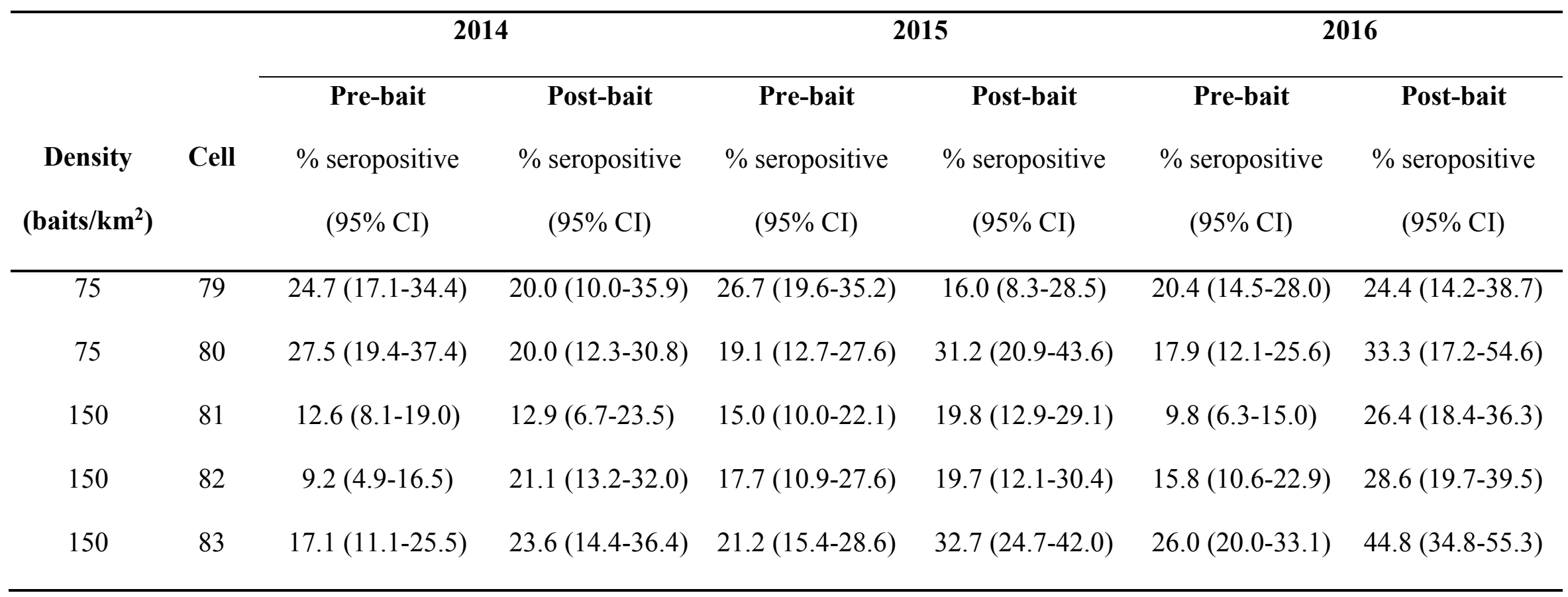

